\title{
Editorial
}

\section{From the Local to the Global: Fifty Years of Historical Research on Tuberculosis}

In 2012, some 8.6 million people fell ill with tuberculosis (TB) and another 1.3 million died from the disease. After HIV/AIDS, TB is the greatest killer of people today that is caused by a single infectious agent. But TB has long been seen as a major danger to public health. As such the history of its impact and efforts to control it has been particularly substantial.

In early 2015, I will present a special virtual issue, which showcases articles published in Medical History between 1962 and 2014. These publications demonstrate the main themes and issues in the scholarship on TB, as well as the shifting and varied approaches that historians have taken to the study of the disease.

The earliest articles in this special issue explore when, where and how the first human beings became infected with the tubercle bacillus and why the disease spread so rapidly in the modern period. ${ }^{1}$ Historians, however, have also focussed on major scientific discoveries, ranging from Robert Koch's identification of the tuberculosis pathogen in 1882, as explored by Christoph Gradmann in this issue, ${ }^{2}$ to the BCG vaccine that was first used on human beings in 1921. And they have furthermore addressed attempts to contain and eradicate the disease, focusing not just on the sanatorium and vaccination but also on legislation. Richard Coker's article, for instance, examines changes in the provisions regarding TB in the Public Health Act in Britain between 1875 till 1984, ${ }^{3}$ while Linda Bryder's article explores proposed and adopted legislation in New Zealand in the late nineteenth and early twentieth centuries to prevent the immigration of TB sufferers. ${ }^{4}$

While the first histories of TB focused mostly on the UK, the USA and Europe, today TB scholarship covers a vast range of countries and is increasingly concerned with the interaction between the local and the global. My own article in this collection, for example, builds on the pioneering work by Niels Brimnes on the role of the WHO in TB control in India ${ }^{5}$ and explores the mass BCG vaccination campaigns sponsored by UNICEF and the

${ }^{1}$ H.C. Chalke, 'The Impact of Tuberculosis on History, Literature and Art', Medical History, 6, 3 (1962), 301-18; Keith Manchester, 'Tuberculosis and Leprosy in Antiquity: An Interpretation', Medical History, 28, 2 (1984), 162-73.

2 Christoph Gradmann, 'Robert Koch and the Pressures of Scientific Research: Tuberculosis and Tuberculin', Medical History, 45, 1 (2001), 1-32; See also his 'Laboratories take control: Robert Koch and the tubercle bacillus', in Alexander Medcalf, Henrice Altink, Monica Saavedra and Sanjoy Bhattacharya (eds), Tuberculosis: A Short History (Hyderabad: Orient Black Swan, 2013), 10-11.

${ }^{3}$ Richard Coker, 'Civil Liberties and Public Good: Detention of Tuberculosis Patients and the Public Health Act 1984', Medical History, 45, 3 (2001), 341-58.

4 Linda Bryder, "A Health Resort for Consumptives": Tuberculosis and Immigration to New Zealand, 1880-1914', Medical History, 40, 4 (1996), 453-71.

5 Niels Brimnes, 'Vikings against Tuberculosis: The International Tuberculosis Campaign in India, 19481951', Bulletin of the History of Medicine, 81, 2 (2007), 407-30; Brimnes, 'BCG Vaccination and WHO's Global Strategy for Tuberculosis Control 1948-1983', Social Science \& Medicine, 67, 5 (2008), 863-73; Christian W. McMillen and Niels Brimnes, 'Medical Modernization and Medical Nationalism: Resistance to Mass Tuberculosis Vaccination in Post-Colonial India, 1948-1955', Comparative Studies in Society and History, 52, 1 (2010), 180-209; Brimnes 'The global tuberculosis control programme of WHO', in Alexander Medcalf, Henrice Altink, Monica Saavedra and Sanjoy Bhattacharya (eds), Tuberculosis, 19-20. 
WHO in the anglophone Caribbean. ${ }^{6}$ Another major shift in the scholarship is the move away from a linear and positivist account of TB control. Gradmann, for instance, shows that Koch failed to present tuberculin as a remedy because of his understanding of TB as a bacterial invasion and his heavy reliance on animal pathology, while Keir Waddington in his article on bovine TB highlights that even though the medical establishment had long advocated routine tuberculin testing as the best means to stamp out this type of TB, opposition from farmers and bureaucratic and professional tensions caused this policy to be implemented in the UK as late as $1964 .^{7}$

The scholarship on TB has also been enriched in recent years by more social and cultural approaches. Margaret Campbell's article provides a welcome addition to existing work on sanatoria. It shows that the treatment regime as studied by previous scholars required specific architectural and design features that intersected in various ways with modernist design. Campbell mentions, eg. that the famous Paimio chair by the Finnish designer Alvar Aalto was originally designed as a 'cure' chair for a sanatorium. ${ }^{8}$ And another Nordic study in this issue, Teemu Ryymin's article on tuberculosis-threatened children in Norway between 1900 and 1960, illustrates the benefits of paying close attention to language. Ryymin explores the rise of the category 'tuberculosis-threatened children', the tensions between the social and medical aspects of this category, and the practices that it gave rise to. ${ }^{9}$ Ryymin's article also shows along with several others in this issue that historians of TB are increasingly placing their national case studies within a wider framework and explore the transnational movement of ideas and practices.

The broader geographical range, comparative work, and social and cultural approaches have done much to enhance our understanding of the history of TB. Yet there is still scope for further work. Keir Waddington's article is one of few studies on bovine TB. Equally understudied are various non-pulmonary types of TB and only recently has multidrug resistant TB begun to receive scholarly attention. ${ }^{10}$ And while many articles in this collection have not ignored TB sufferers, they have been concerned mostly with scientists, medical professionals and authorities. While we have accounts of some famous TB sufferers, such as George Orwell, whose battle with the disease has recently been explored at length by Helen Bynum, ${ }^{11}$ the majority of sufferers were poor men and women who have left us no first-hand accounts. Yet we can get glimpses of their experiences in a variety of sources. The Rockefeller's International Health Board that did a TB survey in Jamaica in the 1930s, for instance, took numerous photographs of TB sufferers in their own homes and added to these detailed notes of their lives. By piecing together such material along with oral interviews of men and women who were inmates of sanatoria or subject to TB screenings, inoculations and ambulatory drug regimes in the post-war years, historians can gain a clearer understanding of the impact of the various methods to contain, control

\footnotetext{
${ }^{6}$ Henrice Altink, “'Fight TB with BCG”: Mass Vaccination Campaigns in the British Caribbean, 1951-56', Medical History, 58, 4 (2014), 475-97.

${ }^{7}$ Keir Waddington, 'To Stamp out "so terrible a Malady": Bovine Tuberculosis and Tuberculin Testing in Britain, 1890-1939', Medical History, 48, 1 (2004), 29-48.

${ }^{8}$ Margaret Campbell, 'What Tuberculosis did for Modernism: The Influence of a Curative Environment on Modernist Design and Architecture', Medical History, 49, 4 (2005), 463-88.

9 Teemu Ryymin, “Tuberculosis-threatened Children”: The Rise and Fall of a Medical Concept in Norway, c. 1900-1960', Medical History, 52, 3 (2008), 347-64.

${ }^{10}$ For recent work on drug-resistant TB, see Dennis Flazon, Ernesto Jaramillo, Mario C. Ravilglione and Karin Weyer, 'A short history of drug-resistant tuberculosis', in Alexander Medcalf, Henrice Altink, Monica Saavedra and Sanjoy Bhattacharya (eds), Tuberculosis, 36-7; Peter Pringle, Experiment Eleven: Dark Secrets behind the Discovery of a Wonder Drug (London: Bloomsbury, 2013).

${ }^{11}$ Helen Bynum, Spitting Blood (Oxford: Oxford University Press, 2012).
} 
and eradicate TB. And a final area in which TB scholarship can move is that of longitudinal and global studies of TB eradication, which has been made possible by the availability of large online datasets, such as the TB database, a joint initiative of the Stanford University school of Medicine and MIT's Broad Institute.

\section{HENRICE ALTINK}

Department of History, University of York, UK

Email: henrice.altink@york.ac.uk 